\title{
Effect of 2,4-Diacetylphloroglucinol on Pythium: Cellular Responses and Variation in Sensitivity Among Propagules and Species
}

\author{
Jorge T. de Souza, Christine Arnould, Chrystel Deulvot, Philippe Lemanceau, \\ Vivienne Gianinazzi-Pearson, and Jos M. Raaijmakers
}

First and sixth authors: Wageningen University and Research Centre (WUR), Department of Plant Sciences, Laboratory of Phytopathology, Binnenhaven 5, P.O. Box 8025, 6709 PD, Wageningen, The Netherlands; second, third, and fourth authors: UMR INRA/Université de Bourgogne BBCE-IPM, Centre de Microbiologie du Sol et de I'Environment, INRA, BV 1540, 21034 Dijon Cedex, France; and fifth author: INRA-CMSE, Laboratoire de Recherches sur la Flore Pathogène dans de Sol, 17 rue Sully, 21034 Dijon Cedex, France. Accepted for publication 12 March 2003.

\section{ABSTRACT}

de Souza, J. T., Arnould, C., Deulvot, C., Lemanceau, P., GianinazziPearson, V., and Raaijmakers, J. M. 2003. Effect of 2,4-diacetylphloroglucinol on Pythium: Cellular responses and variation in sensitivity among propagules and species. Phytopathology 93:966-975.

The antibiotic 2,4-diacetylphloroglucinol (2,4-DAPG) plays an important role in the suppression of plant pathogens by several strains of Pseudomonas spp. Based on the results of this study, there is variation within and among Pythium spp. to 2,4-DAPG. Also, various propagules of Pythium ultimum var. sporangiiferum, that are part of the asexual stage of the life cycle, differ considerably in their sensitivity to 2,4-DAPG. Mycelium was the most resistant structure, followed by zoosporangia, zoospore cysts, and zoospores. Additionally, we report for the first time that $\mathrm{pH}$ has a significant effect on the activity of 2,4-DAPG, with a higher activity at low $\mathrm{pH}$. Furthermore, the level of acetylation of phloroglucinols is also a major determinant of their activity. Transmission electron microscopy studies revealed that 2,4-DAPG causes different stages of disorganization in hyphal tips of Pythium ultimum var. sporangiiferum, including alteration (proliferation, retraction, and disruption) of the plasma membrane, vacuolization, and cell content disintegration. The implications of these results for the efficacy and consistency of biological control of plant-pathogenic Pythium spp. by 2,4-DAPGproducing Pseudomonas spp. are discussed.

Additional keywords: microbial ecology, soilborne pathogens, ultrastructure.
Phloroglucinols (PG) are phenolic, secondary metabolites produced by plants, algae, and bacteria $(2,3,6,22,25,58,59)$. More than 60 PG derivatives have been described and were reported to have antiviral, antimicrobial, ichthyotoxic, insect and mammal antifeedant, antihelminthic, phytotoxic, antioxidant, cytotoxic, antitumor, and plant growth-regulating activities (1,11,15,23$26,30,50,51,60)$. The antimicrobial activity of these compounds, and in particular of 2,4-diacetylphloroglucinol (2,4-DAPG), has received considerable attention in the area of biological control of plant diseases.

Numerous studies have demonstrated that 2,4-DAPG-producing Pseudomonas spp. can suppress a wide variety of plant pathogens, including fungi, bacteria, and nematodes $(11,12,17,20,26,27,32$, 47,49,59). Among the plant-pathogenic fungi, Gaeumannomyces graminis var. tritici, Thielaviopsis basicola, Fusarium oxysporum f. sp. radicis-lycopersici, and the oomycete Pythium ultimum can be effectively controlled by 2,4-DAPG-producing Pseudomonas strains $(17,20,47,49,59)$. The determinative role of 2,4-DAPG in disease suppression by Pseudomonas strains has been demonstrated by (i) the use of mutants deficient in 2,4-DAPG production $(11,12,26,45,59)$, (ii) complementation of 2,4-DAPG-deficient mutants and concomitant restoration of biocontrol activity $(11,12$, 26,59), and (iii) expression of 2,4-DAPG biosynthetic genes in heterologous, nonproducing strains, thereby conferring biocontrol activity or enhanced activity $(2,46,59)$.

Reporter gene systems (33) and analytical techniques (53) have further demonstrated that $2,4-\mathrm{DAPG}$ is produced in situ by both

Corresponding author: J. M. Raaijmakers; E-mail address: Jos.Raaijmakers@wur.nl

Publication no. P-2003-0527-02R

(c) 2003 The American Phytopathological Society introduced Pseudomonas strains and indigenous Pseudomonas populations $(7,17,26,38,41)$. Pseudomonas strains that produce 2,4-DAPG also produce monoacetylphloroglucinol (MAPG) and, depending on the nutritional environment, the ratio of MAPG to 2,4-DAPG may change (17). In addition to MAPG and 2,4DAPG, PG has been purified from cultures of a bacterium, classified as Aeromonas hydrophila, found on decayed roots of red pine seedlings (48).

In spite of significant progress in our understanding of the biosynthesis and regulation of 2,4-DAPG-production in Pseudomonas strains $(2,3,5,44,62)$, little attention has been given to fungal responses to 2,4-DAPG and to its mode of action. Most studies on the sensitivity of plant-pathogenic fungi to 2,4-DAPG take into account only one species or isolate of the target pathogen and consider only one particular stage in the life cycle of a pathogen, usually mycelial growth $(26,32,36)$. Most life cycles of pathogens, however, are complex and comprise numerous pathogen structures and infectious propagules. For example, oomycete pathogens can infect host tissues by means of multiple propagules, including mycelium, zoosporangia, zoospores, and oospores. Understanding the variation in sensitivity of different phases of the life cycle of a pathogen to a specific biocontrol trait will give more insight into the potential efficacy of biocontrol agents harboring that trait.

In this study, we investigated the response of Pythium spp. to 2,4-DAPG. Pythium spp. are ubiquitous pathogens of many important crops around the world and possess a high level of diversity with more than 200 species described $(16,57)$. Many of these species can occur simultaneously at the same site and, often, more than one species can infect a certain host plant (9). We determined the variation in sensitivity of 14 Pythium isolates to 2,4-DAPG; the isolates were obtained from multiple hosts and represent eight 
species. The sensitivity of various infectious propagules of $P y$ thium ultimum var. sporangiiferum to 2,4-DAPG was studied in detail, with special emphasis on those propagules that are part of the asexual life cycle. The effects of $\mathrm{pH}$ and level of acetylation on activity of phloroglucinols against mycelial growth of Pythium ultimum var. sporangiiferum were assessed also. To understand the mode of action of 2,4-DAPG, ultrastructural changes induced by 2,4-DAPG in hyphal tips of Pythium ultimum var. sporangiiferum were studied by transmission electron microscopy (TEM).

\section{MATERIALS AND METHODS}

Organisms and culture conditions. Characteristics of the $P y$ thium isolates used in this study are shown in Table 1. Pythium isolates were grown routinely on potato dextrose agar (PDA; Oxoid Ltd., Basingstoke, Hampshire, England) or on V8-juice agar (V8; N. V. Campbell Foods, Puurs, Belgium) at $25^{\circ} \mathrm{C}$. For production of zoospores, Pythium ultimum var. sporangiiferum was grown on $\mathrm{V} 8$ amended with $\mathrm{CaCO}_{3}$ at $10 \mathrm{~g} \mathrm{liter}^{-1}$ (V8+). Mycelial plugs of all Pythium isolates were stored in sterile mineral oil at $15^{\circ} \mathrm{C}$. Pseudomonas fluorescens strain P60 was isolated from the wheat rhizosphere and identified with the API 20 NE test (BioMérieux sa., Lyon, France). Strain P60 was grown on Pseudomonas agar F (PSA; Difco Laboratories, Detroit) or on King's medium B (KMB) agar (29). The bacterial strain was stored at $-80^{\circ} \mathrm{C}$ in $\mathrm{KMB}$ broth supplemented with glycerol to a final concentration of $40 \%$ (vol/vol). For TEM studies, Pythium ultimum var. sporangiiferum was grown on KMB agar.

Antibiotics. The antibiotics used were PG, MAPG, and 2,4DAPG. PG (1,3,5-trihydroxybenzene) and MAPG (2,4,6-trihydroxyacetophenone monohydrate) were obtained from SigmaAldrich Chemie GmbH (Steinheim, Germany). 2,4-DAPG was purified from cultures of Pseudomonas fluorescens strain P60 by high pressure liquid chromatography (HPLC) followed by photodiode array spectroscopy to determine peak purity and identity. Purification protocols and the HPLC-photodiode array spectroscopy system were described previously (41). All antibiotics were dissolved in $96 \%$ ethanol (Merck KGaA, Darmstadt, Germany). In experiments where activity of the antibiotics was determined, all treatments, including controls, had the same concentration of ethanol.

Wheat root exudates. Seed of wheat cv. Pagode were surface sterilized by soaking in $96 \%$ ethanol for $30 \mathrm{~s}$ and washing once with sterile demineralized water, followed by agitation in $1.5 \%$
$\mathrm{NaOCl}$ supplemented with $1 \%$ Tween 20 . After $1.5 \mathrm{~h}$, seed were washed three times in sterile demineralized water, incubated again for $15 \mathrm{~min}$ in $1.5 \% \mathrm{NaOCl}$, and washed three times in sterile demineralized water. Seed were germinated on one-fifth-strength PDA plates at $18^{\circ} \mathrm{C}$ in a climate-controlled chamber with a $12-\mathrm{h}$ photoperiod. Plates containing germinated seed showing any sign of contamination were discarded. After 11 days, germinated seedlings without seed remnants were transferred to culture tubes (De Wit culture tubes; LAB Associated BV, Oudenbosch, The Netherlands) containing $5 \mathrm{ml}$ of sterile diluted (2:3, vol/vol) Hoaglund's solution. After 7 days of incubation at $18^{\circ} \mathrm{C}$ in a climate-controlled chamber with a 12-h photoperiod, plants were removed and the nutrient solutions containing the root exudates were checked for contamination by plating samples onto KMB and PDA. Contaminated samples were discarded. Sterile root exudates were stored at $-20^{\circ} \mathrm{C}$.

Effect of 2,4-DAPG on mycelial growth of different Pythium spp. Effect of 2,4-DAPG on mycelial growth of 14 different Pythium isolates was tested on PDA plates amended with 2,4DAPG. The initial $\mathrm{pH}$ of the agar was adjusted to 6.5. 2,4-DAPG concentrations ranged from 0 to $300 \mu \mathrm{g} \mathrm{ml}^{-1}$ with intervals of $8 \mu \mathrm{g}$ $\mathrm{ml}^{-1}$. Mycelial plugs $(0.5 \mathrm{~cm}$ in diameter $)$ were obtained from 3-day-old cultures grown on PDA and transferred to PDA plates amended with different concentrations of 2,4-DAPG. Mycelial growth was recorded every $24 \mathrm{~h}$ for 7 days. The concentration necessary to inhibit $50 \%$ of the mycelial growth $\left(\mathrm{EC}_{50}\right.$ value) was assessed. The minimal inhibitory concentration (MIC), defined as the minimum concentration necessary to completely (100\%) inhibit mycelial growth, was determined. Each treatment had six replicates and the experiment was performed three times.

Effect of 2,4-DAPG on zoosporangia. Mycelial plugs $(1.5 \mathrm{~cm}$ in diameter) were cut from Pythium ultimum var. sporangiiferum agar cultures grown for 3 days on $\mathrm{V} 8+$ at $25^{\circ} \mathrm{C}$. Mycelial plugs were transferred to petri plates and flooded with $15 \mathrm{ml}$ of a solution containing 2,4-DAPG at final concentrations of $0,2,4,8$, and $16 \mu \mathrm{g} \mathrm{ml}^{-1}$. After 4 days at $25^{\circ} \mathrm{C}$, the number of zoosporangia formed in one microscopic field at magnification of $\times 100$ (Leitz Wetzlar Dialux $20 \mathrm{~EB}$, Germany), corresponding to an area of $3.14 \mathrm{~mm}^{2}$, was determined. The diameter of 10 randomly selected zoosporangia formed per treatment after 4 days was measured with an ocular micrometer (Periplan 10X M, Leitz). Each treatment had five replicates and the experiment was performed twice.

Effect of 2,4-DAPG on zoospores and zoospore cysts. Zoospores of Pythium ultimum var. sporangiiferum were produced

TABLE 1. Effect of 2,4-diacetylphloroglucinol (2,4-DAPG) on mycelial growth of different Pythium spp.

\begin{tabular}{|c|c|c|c|c|}
\hline Pythium spp. & Isolate $^{x}$ & Origin & $\mathrm{EC}_{50}\left(\mu \mathrm{g} \mathrm{ml}^{-1}\right)^{\mathrm{y}}$ & $\operatorname{MIC}\left(\mu \mathrm{g} \mathrm{ml}^{-1}\right)^{\mathrm{z}}$ \\
\hline P. aphanidermatum & 311-PPO & Cucumber & $36 \mathrm{~b}$ & 48 \\
\hline P. aristosporum & CBS 263.38 & Wheat & $20 \mathrm{c}$ & 32 \\
\hline$P$. deliense & V1-PPO & Cucumber & $300 \mathrm{a}$ & $>300$ \\
\hline P. intermedium & LBO & Hyacinth & $28 \mathrm{bc}$ & 48 \\
\hline P. irregulare & ATCC 1120 & Wheat & $28 \mathrm{bc}$ & 48 \\
\hline P. irregulare & LBO & Crocus & $20 \mathrm{c}$ & 56 \\
\hline P. macrosporum & 111-LBO & Lily & $20 \mathrm{c}$ & 40 \\
\hline P. ultimum & IRS & Sugar beet & $34.7 \mathrm{~b}$ & 56 \\
\hline P. ultimum var. sporangiiferum & CBS 219.65 & Wheat & $20 \mathrm{c}$ & 32 \\
\hline P. ultimum var. ultimum & CBS 725.94 & Wheat & $20 \mathrm{c}$ & 32 \\
\hline$P$. volutum & CBS 699.83 & Wheat & $<8$ & 8 \\
\hline
\end{tabular}

${ }^{x}$ CBS, Collection of Fungal Cultures, Utrecht, The Netherlands; LBO, Applied Plant Research, section Flower Bulbs, Lisse, The Netherlands; PPO, Applied Plant Research, Naaldwijk, The Netherlands; ATCC, American Type Culture Collection, University Blvd., Manassas, Virginia; IRS, Institute for Rational Sugar Production, Bergen op Zoom, The Netherlands.

${ }^{\text {y }} \mathrm{EC}_{50}=$ concentration of 2,4-DAPG necessary to inhibit radial mycelial growth by 50\%. Mean values followed by the same letter are not statistically different according to Tukey's test $(P=0.05)$.

${ }^{\mathrm{z}} \mathrm{MIC}=$ minimal concentration of 2,4-DAPG causing $100 \%$ inhibition of mycelial growth. Medium used was potato dextrose agar (pH 6.5) and inhibition was assessed every $24 \mathrm{~h}$ during 7 days of incubation at $25^{\circ} \mathrm{C}$. Concentrations of 2,4-DAPG varied from 0 to $300 \mu \mathrm{g} \mathrm{ml}{ }^{-1}$ with intervals of $8 \mu \mathrm{g} \mathrm{ml}{ }^{-1}$. Each value is based on three experiments with six replicates per treatment. 
using a modification of a method described by Zhou and Paulitz (63). Pythium ultimum var. sporangiiferum was grown on V8+ for 3 days at $25^{\circ} \mathrm{C}$. The full-grown agar plates were cut into $2-\mathrm{cm}-$ wide strips and one-half of the strip was transferred to another petri plate; both plates were flooded with $20 \mathrm{ml}$ of sterile water and kept at $25^{\circ} \mathrm{C}$. After $1 \mathrm{~h}$, the water was discarded and replaced with the same volume of water. Plates were incubated at $18^{\circ} \mathrm{C}$ for 4 days, water was removed and replaced with the same volume and incubated at $18^{\circ} \mathrm{C}$ for $2 \mathrm{~h}$, and zoospores were collected and concentrated using a $0.45-\mu \mathrm{m}$ nylon filter (ZapCap; Schleicher \& Schuell GmbH, Dassel, Germany). Suspensions containing 20,000 to 40,000 zoospores $\mathrm{ml}^{-1}$ typically were obtained. Aliquots of $50 \mu$ of a suspension containing Pythium ultimum var. sporangiiferum at 25,000 zoospores $\mathrm{ml}^{-1}$ were transferred to 96-well microtiter plates (Greiner BV, Alphen aan den Rijn, The Netherlands) and mixed in a 1:1 ratio with solutions of 2,4-DAPG to obtain final 2,4-DAPG concentrations of $0.0,0.2,0.4,0.8,1.6$, and $3.2 \mathrm{ng} \mathrm{ml}^{-1}$. The number of swimming, encysted, germinated, and disintegrated zoospores was counted under an inverted microscope (Axiovert 10; Carl Zeiss, Jena, Germany). Treatments had five replicates and the experiment was performed five times.

The effect of 2,4-DAPG on germination of encysted zoospores was studied in more detail in separate experiments. These experiments were performed in both water and wheat root exudates. To study germination in water, encystment of zoospores of Pythium ultimum var. sporangiiferum was induced by vortexing a suspension containing 25,000 zoospores $\mathrm{ml}^{-1}$ for $25 \mathrm{~s}$. Encysted zoospores were transferred to 96-well microtiter plates and mixed with 2,4-DAPG solutions to obtain final 2,4-DAPG concentrations of $0,0.8,1.6,2.0,2.4,2.8,3.2,4.0,5.2$, and $6.4 \mu \mathrm{g} \mathrm{ml}^{-1}$. To study the effect of wheat root exudates, a zoospore suspension containing 50,000 zoospores $\mathrm{ml}^{-1}$ was vortexed for $25 \mathrm{~s}$; after which encysted zoospores were transferred to microtiter plates and diluted with root exudates to obtain the same final 2,4-DAPG concentrations described above. The final concentration of root exudates was half of the initial root exudates obtained as described previously. Microtiter plates were incubated at $25^{\circ} \mathrm{C}$ and, after $2 \mathrm{~h}$, a drop of $96 \%$ ethanol was added to each well to stop germination. The number of germinated zoospore cysts was determined microscopically. Prior to addition of 2,4-DAPG and wheat root exudates to zoospore suspensions, the initial number of germinated encysted zoospores was determined microscopically. Treatments had five replicates each and the experiment was performed twice.

Effect of acetylation on activity of PG derivatives. The effect of the level of acetylation on the activity of PG derivatives was tested on mycelial growth of Pythium ultimum var. sporangiiferum. PG, MAPG, and 2,4-DAPG have no, one, and two acetyl groups, respectively (Fig. 1). Pythium ultimum var. sporangiiferum was grown on PDA amended with PG, MAPG, or 2,4-DAPG to final concentrations of $0,16,32,48,64,80,100,200$, and $300 \mu \mathrm{g}$ $\mathrm{ml}^{-1}$. Mycelial growth was measured every $24 \mathrm{~h}$ for 7 days and growth rates (millimeters per day) were calculated. Treatments had five replicates and the experiment was performed three times.
Effect of pH on activity of 2,4-DAPG. Pythium ultimum var. sporangiiferum was grown on PDA buffered with $0.0015 \mathrm{M}$ citric acid $\left(0.001 \mathrm{M} \mathrm{C}_{6} \mathrm{H}_{8} \mathrm{O}_{7} \cdot 1 \mathrm{H}_{2} \mathrm{O} ; 0.002 \mathrm{M} \mathrm{Na}_{2} \mathrm{HPO}_{4} \cdot 2 \mathrm{H}_{2} \mathrm{O}\right)$ to a $\mathrm{pH}$ of $4.5,5.5,6.5,7.5$, or 8.0. PDA plates with different $\mathrm{pH}$ were amended with 2,4-DAPG to final concentrations of $0,16,24,32$, and $40 \mu \mathrm{g} \mathrm{ml} \mathrm{m}^{-1}$. Plates were incubated at $25^{\circ} \mathrm{C}$ and mycelial growth was measured every $24 \mathrm{~h}$ for 7 days. Each treatment had 10 replicates and the experiment was performed three times.

Static effect of 2,4-DAPG on mycelial growth. Pythium ultimum var. sporangiiferum was grown on PDA for 3 days and 0.5-cm-diameter mycelial plugs were transferred to PDA plates amended with 2,4-DAPG to final concentrations of $0,8,16,32$, $48,64,96,128,200$, and $300 \mu \mathrm{g} \mathrm{ml}^{-1}$. After 7 days, mycelial plugs that failed to grow on PDA amended with 2,4-DAPG were transferred to PDA ( $\mathrm{pH}$ 6.5) without 2,4-DAPG. Growth was recorded up to 7 days after transfer. Treatments had five replicates and the experiment was performed twice.

TEM studies. Mycelial plugs (6 $\mathrm{mm}$ in diameter) were cut from Pythium ultimum var. sporangiiferum agar cultures grown for 3 days on $\mathrm{KMB}$ at $25^{\circ} \mathrm{C}$. Mycelial plugs were transferred to the center of petri plates containing KMB. Sterile antibiotic assay disks (9 $\mathrm{mm}$ in diameter; Whatman, Springfield Mill, England) were imbibed with solutions containing 2,4-DAPG at final concentrations of $0,25,50,100,200$, and $400 \mu$ disk $^{-1}$. Discs were placed at a distance of $3 \mathrm{~cm}$ from the mycelial plugs. Petri dishes were sealed with parafilm and incubated 5 to 6 days in the dark at $25^{\circ} \mathrm{C}$. Five samples $\left(2 \mathrm{~mm}^{2}\right)$ of agar were collected at the

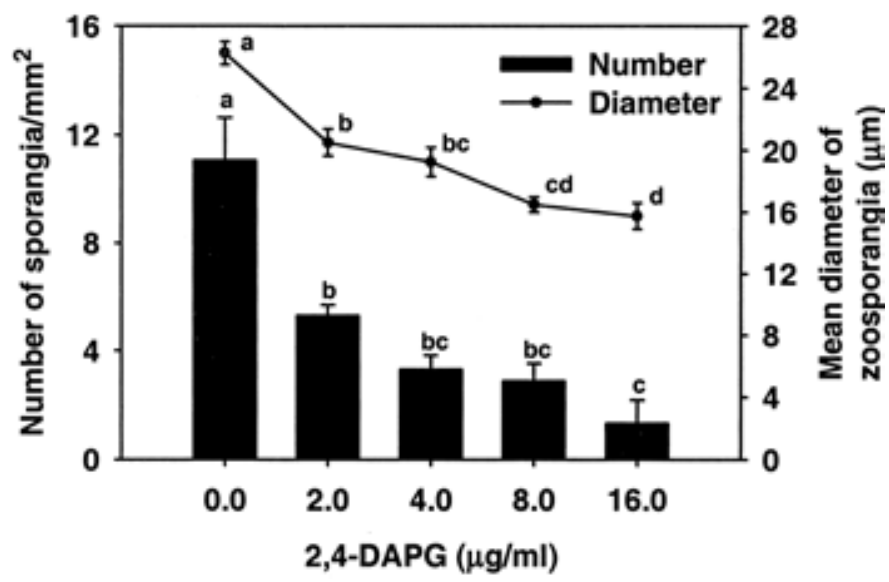

Fig. 2. Effect of 2,4-diacetylphloroglucinol (2,4-DAPG) on formation and diameter of zoosporangia of Pythium ultimum var. sporangiiferum. Mycelial plugs of Pythium ultimum var. sporangiiferum grown on medium without the antibiotic were flooded with solutions of different 2,4-DAPG concentrations. After 4 days of incubation at $25^{\circ} \mathrm{C}$, the number and diameter of 10 sporangia formed per treatment was determined microscopically. Mean values of five replicates are shown. Error bars represent the standard error of the mean. For each of the two parameters, means followed by the same letter are not significantly different according to Tukey's studentized range test $(P=0.05)$. The experiment was performed twice and representative results are shown.
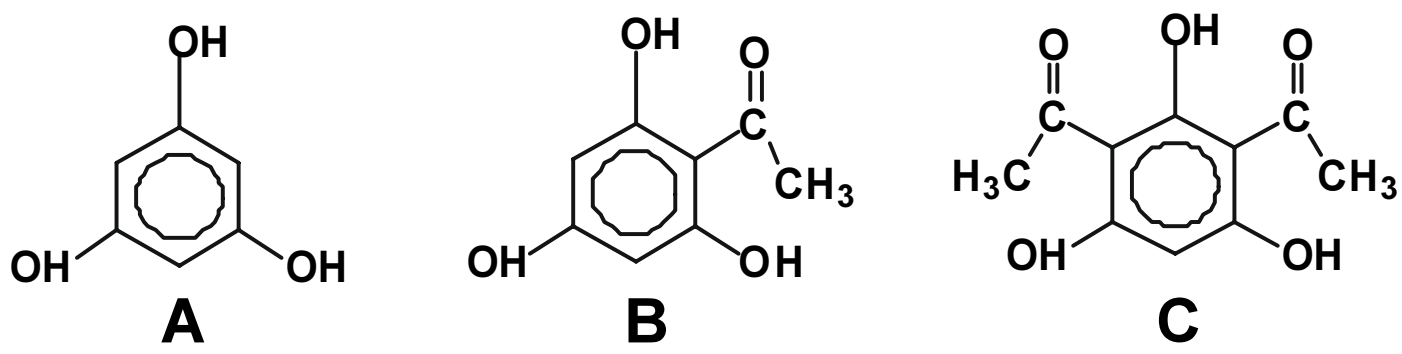

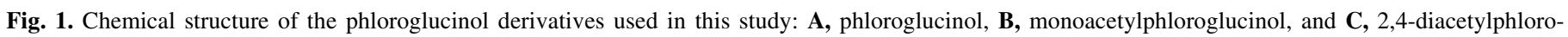
glucinol. 
margin of Pythium ultimum var. sporangiiferum cultures exposed or not to $400 \mu \mathrm{g}$ of 2,4-DAPG per disk. Samples were fixed overnight at $4{ }^{\circ} \mathrm{C}$ in $2 \%$ glutaraldehyde buffered in $0.1 \mathrm{M}$ cacodylate ( $\mathrm{pH}$ 7.2), washed in the same buffer, then dehydrated in a graded ethanol series and embedded in Epon (Prolabo, France) or LR White medium grade resin (Oxford Instrument, France).

Epon-embedded samples were postfixed with $1 \%$ osmium tetroxide before ethanol dehydration (21). Ultrathin sections $(0.1 \mu \mathrm{m})$ were cut with a diamond knife (Reicher Ultracut microtone). For ultrastructural observations, Epon sections were cut onto copper grids and double contrasted by post-staining with $3 \%$ uranyl acetate in $50 \%$ ethanol (56) followed by lead citrate (42). To locate $\beta(1,4)$ - and $\beta(1,6)$-glycosylated compounds (glycoproteins and polysaccharides), Epon-embedded samples were subjected to the periodic acid thiocarbohydrazide silver proteinate (PATAg) reaction according to Thièry (52).

LR White-embedded sections were collected on golden grids coated with collodion for analytical immunocytochemistry using an indirect immunogold labeling technique for the detection of $\beta(1,3)$-glucans (31). Samples on grids were incubated overnight at $4^{\circ} \mathrm{C}$ in a mouse monoclonal antibody raised against $\beta(1,3)$ glucopyranose polymers (Biosupplies Australia, Australia) which has previously been shown to be specific for $\beta(1,3)$-glucans of the

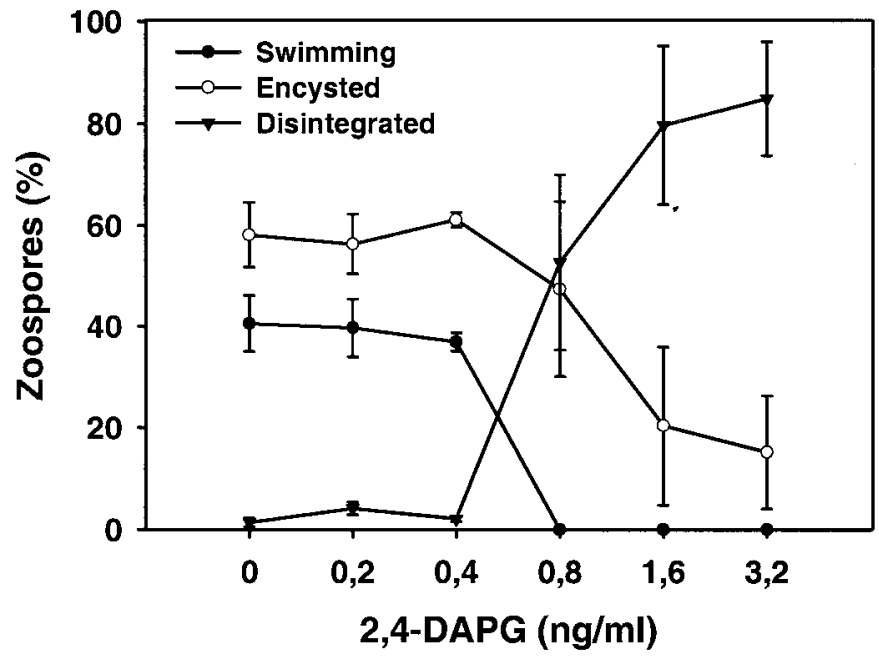

Fig. 3. Effect of 2,4-diacetylphloroglucinol (2,4-DAPG) on zoospores of Pythium ultimum var. sporangiiferum. Zoospores were exposed to different concentrations of 2,4-DAPG and the percentage of swimming, encysted, and disintegrated zoospores were determined microscopically. Mean values of five replicates are given. Error bars represent the standard error of the mean. The experiment was performed five times and representative results are shown. cell wall (31). The antibody was diluted 1,000 or 500 times in Tris buffer saline with $1 \%$ bovine serum albumin. After rinsing, sections were incubated for $1 \mathrm{~h}$ in a gold-labeled $(15 \mathrm{~nm})$ goat antimouse polyclonal antibody (Tebu Biocell, France) diluted 20 times to detect the primary antibody. Immunological control sections were prepared by omitting the monoclonal antibody during the first incubation step. All sections were counterstained for 10 min with $3 \%$ aqueous uranyl acetate before observation in a transmission electron microscope (Hitachi H7500) at $80 \mathrm{kV}$.

The effect of 2,4-DAPG on Pythium ultimum var. sporangiiferum mycelium was evaluated by quantifying hyphal responses on Epon-embedded double-contrasted sections in the following categories: (i) dense cytoplasm with few vacuoles (young), (ii) many vacuoles in the cell lumen, (iii) beginning of cell content disorganization, and (iv) deteriorated or empty cell contents (dead). The effect of 2,4-DAPG on Pythium ultimum var. sporangiiferum cell wall synthesis was determined by observing LR White immunogold labeled sections. All experiments were performed twice.

Statistical analysis. Data were analyzed by analysis of variance followed by Tukey's studentized range test after certifying normal distribution and homogeneity of variances (SAS institute, Inc., Cary, NC). All experiments were performed at least twice and representative results are shown.

\section{RESULTS}

Effect of 2,4-DAPG on mycelial growth of different Pythium spp. Mycelial growth of 14 Pythium isolates, obtained from multiple host plants and representing eight different species, was completely inhibited at 2,4-DAPG concentrations ranging from 8 to more than $300 \mu \mathrm{g} \mathrm{ml}^{-1}$ (Table 1). Pythium volutum CBS 699.83 was the most sensitive isolate, whereas Pythium deliense V1-PPO was relatively insensitive to 2,4-DAPG. Mycelial growth of the other Pythium isolates was completely inhibited at 2,4DAPG concentrations ranging from 32 to $72 \mu \mathrm{g} \mathrm{ml} \mathrm{m}^{-1}$. Pythium ultimum var. sporangiiferum isolate CBS 219.65 was used for a detailed analysis of the effect of 2,4-DAPG on different propagules, including zoosporangia, zoospores, and zoospore cysts.

Effect of 2,4-DAPG on zoosporangia. The antibiotic 2,4DAPG had a significant effect on both the formation and the diameter of zoosporangia of Pythium ultimum var. sporangiiferum (Fig. 2). The number of newly formed zoosporangia decreased by approximately $50 \%$ when exposed to 2,4-DAPG at $2.0 \mu \mathrm{g} \mathrm{ml}^{-1}$. The diameter of the newly formed zoosporangia, an indicative measure of their ripening, decreased from 26 to $16 \mu \mathrm{m}$ with increasing concentrations of 2,4-DAPG.

Effect of 2,4-DAPG on zoospores and zoospore cysts. The behavior of Pythium ultimum var. sporangiiferum zoospores was
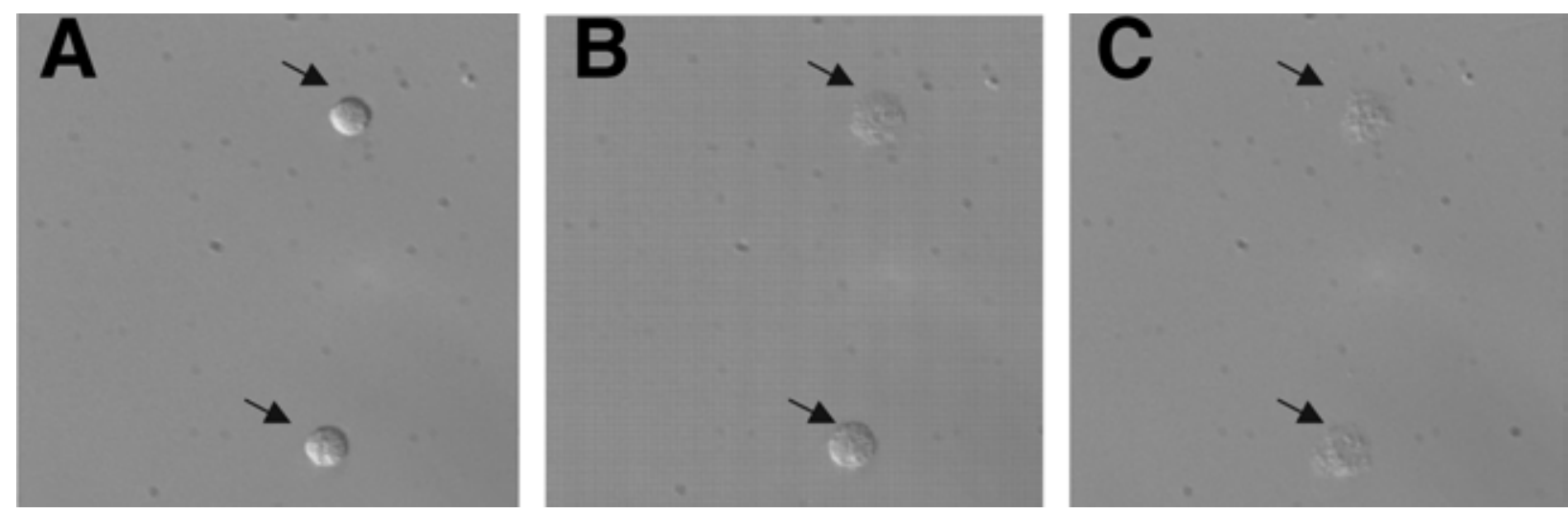

Fig. 4. Effect of 2,4-diacetylphloroglucinol (2,4-DAPG) on zoospores of Pythium ultimum var. sporangiiferum: A, round-shaped zoospores, B, disintegration, and $\mathbf{C}$, disappearance. Arrows indicate zoospores of Pythium ultimum var. sporangiiferum (magnification $\times 100$ ). The concentration of 2,4-DAPG was $3.2 \mathrm{ng} \mathrm{ml}^{-1}$ and the zoospore suspension contained $10^{4}$ zoospores $\mathrm{ml}^{-1}$. 
adversely affected by 2,4-DAPG at concentrations of $0.8 \mathrm{ng} \mathrm{ml}^{-1}$ and higher (Fig. 3). At a concentration of $0.8 \mathrm{ng} \mathrm{ml}^{-1}$, all zoospores stopped swimming and approximately $50 \%$ of the zoospores disintegrated (Fig. 4). The time for disintegration to occur depended on the concentration of 2,4-DAPG. At concentrations of $0.8 \mathrm{ng} \mathrm{ml}^{-1}$, disintegration of the zoospores occurred in approximately $20 \mathrm{~min}$ and at concentrations of $3.2 \mathrm{ng} \mathrm{ml}^{-1}$ it only took $3 \mathrm{~min}$ (data not shown).

The effect of 2,4-DAPG on germination of encysted zoospores was studied in water and in wheat root exudates. Wheat root exudates were included because responses to antibiotics may differ depending on the nutritional conditions. In experiments conducted in water, $15.8 \%$ of the total number of encysted zoospores had germinated prior to addition of 2,4-DAPG. There was no significant effect of 2,4-DAPG on the percentage of germinated zoospore cysts at concentrations up to $2.8 \mu \mathrm{g} \mathrm{ml} \mathrm{g}^{-1}$ (Fig. 5A). At a 2,4-DAPG concentration of $3.2 \mu \mathrm{g} \mathrm{ml}^{-1}$, there was a significant increase in germination of encysted zoospores, which was observed in all replicate experiments. At 2,4-DAPG concentrations higher than $3.2 \mu \mathrm{g} \mathrm{ml}{ }^{-1}$, germination of encysted zoospores of Pythium ultimum var. sporangiiferum significantly decreased.

In wheat root exudates, germination of encysted zoospores of Pythium ultimum var. sporangiiferum was approximately $100 \%$ (Fig. 5B). At concentrations up to $2.4 \mu \mathrm{g} \mathrm{ml}^{-1}$, there was no adverse effect of 2,4-DAPG on germination, whereas concentrations ranging from 2.8 to $6.4 \mu \mathrm{g} \mathrm{ml}^{-1}$ led to a significant decrease in cyst germination. Concentrations of 2,4-DAPG at $6.4 \mu \mathrm{g} \mathrm{m} \mathrm{m}^{-1}$ reduced the percentage of germinated cysts even below the initial percentage of $11 \%$ germinated zoospore cysts that were present prior to addition of 2,4-DAPG, which may suggest that relatively high concentrations of 2,4-DAPG cause lysis of germ tubes.

Effect of $\mathbf{p H}$ and level of acetylation on activity. In the absence of 2,4-DAPG, $\mathrm{pH}$ had no significant effect on the growth rate of Pythium ultimum var. sporangiiferum: growth rates were, on average, $23 \mathrm{~mm}$ day $^{-1}$ at a $\mathrm{pH}$ ranging from 4.5 to 8.0 (Fig. 6). In the presence of 2,4-DAPG, growth rates of Pythium ultimum var. sporangiiferum decreased significantly and this decrease was highly dependent on $\mathrm{pH}$. At $\mathrm{pH} 4.5$, mycelial growth of Pythium ultimum var. sporangiiferum was completely inhibited at a 2,4DAPG concentration of $16 \mu \mathrm{g} \mathrm{ml}^{-1}$, whereas a 2,4-DAPG concentration of $40 \mu \mathrm{g} \mathrm{ml}^{-1}$ was not sufficient to completely inhibit mycelial growth at $\mathrm{pH} 7.5$ and 8.0.
The PG derivative 2,4-DAPG was significantly more inhibitory than MAPG and PG (Fig. 7). Mycelial growth of Pythium ultimum var. sporangiiferum was completely inhibited at a 2,4-DAPG concentration of $32 \mu \mathrm{g} \mathrm{ml}^{-1}$; whereas, for MAPG, almost 10 -fold higher concentrations were necessary (Fig. 7). In the presence of PG, Pythium ultimum var. sporangiiferum still could grow at concentrations of $300 \mu \mathrm{g} \mathrm{ml}^{-1}$.

Static effect of 2,4-DAPG on mycelial growth. Pythium ultimum var. sporangiiferum was grown for 7 days on PDA plates amended with different concentrations of 2,4-DAPG. Pythium ultimum var. sporangiiferum could grow, although at reduced level, in the presence of 2,4-DAPG up to a concentration of $32 \mu \mathrm{g} \mathrm{ml}^{-1}$. Mycelial plugs from Pythium ultimum var. sporangiiferum cultures that failed to grow at concentrations higher than $32 \mu \mathrm{g} \mathrm{ml}{ }^{-1}$ were transferred to PDA plates without 2,4-DAPG. The plugs exposed to 48, 64, and $96 \mu \mathrm{g} \mathrm{ml}^{-1}$ regrew on PDA without 2,4-DAPG, whereas the ones exposed to 2,4-DAPG at $128 \mu \mathrm{g} \mathrm{ml}^{-1}$ or higher were not able to grow on PDA plates free of 2,4-DAPG.

TEM studies. For studying ultrastructural changes in hyphal tips of Pythium ultimum var. sporangiiferum exposed to 2,4DAPG, samples were taken at the periphery of Pythium ultimum var. sporangiiferum colonies growing in the absence or presence of 2,4-DAPG. The concentration of 2,4-DAPG used was $400 \mu \mathrm{g}$ per paper disk, which was placed on the surface of the agar medium. In the absence of 2,4-DAPG, most hyphal tips (72\%) showed normal cell morphology, characterized by dense cytoplasm containing numerous organelles (mitochondria, ribosomes, endoplasmic reticulum, and vacuoles) (Table 2; Fig. 8A and B). In the presence of 2,4-DAPG, different stages of disorganization in hyphal tips were observed. A relatively low percentage (10\%) of the hyphal tips had dense cytoplasm (Table 2) containing numerous mitochondria and ribosomes (Fig. 8C and D). Recurrent features observed in the cell contents of hyphal tips exposed to 2,4-DAPG were (i) a well-defined rough endoplasmic reticulum, (ii) the localized alteration (proliferation or disruption) in plasma membrane organization, and (iii) the development of an extensive network of smooth membranous vesicles which appeared to be closely associated with the endoplasmic reticulum (Fig. 8C). A large proportion of the hyphae $(66 \%)$ showed cell content disorganization (Table 2), a degenerated cytoplasm which was bordered by a retracted plasma membrane (Fig. 8E). Hyphal senescence
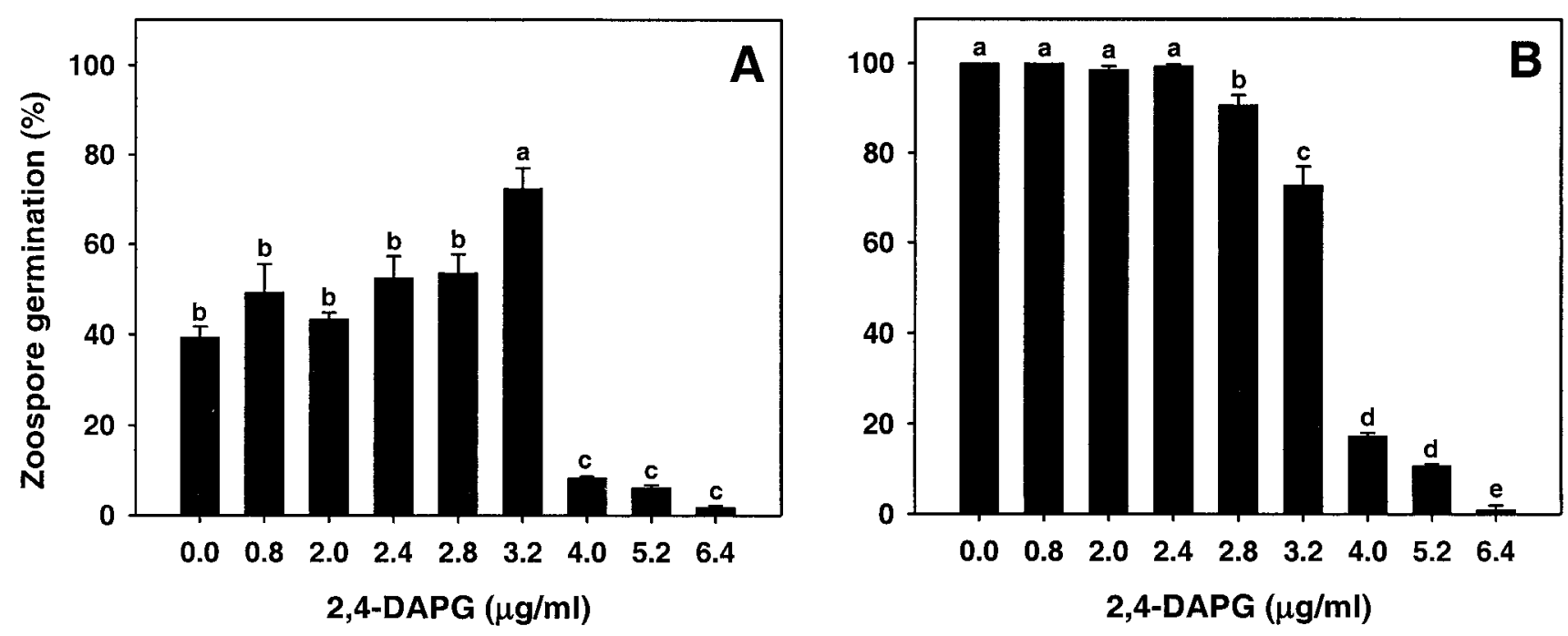

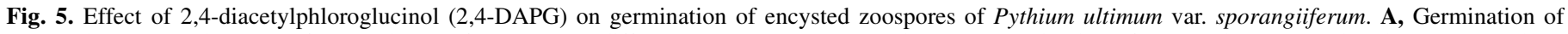

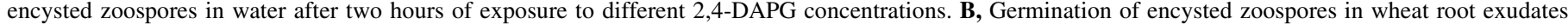

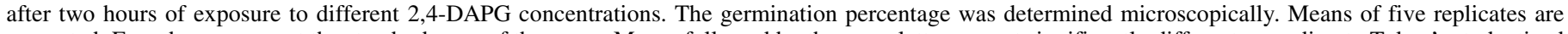

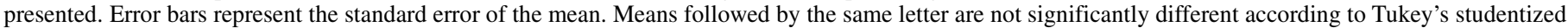
range test $(P=0.05)$. The experiment was performed twice and representative results are shown. 
was accompanied by vacuolization and degeneration of its contents (Fig. 8F). Pythium ultimum var. sporangiiferum hyphal tips growing in the absence of 2,4-DAPG were delimited by a thin electron translucent wall where the cellulosic components were strongly stained by the PATAg reaction (Fig. 8B). The PATAg reaction occurred similarly in cell walls of Pythium ultimum var. sporangiiferum growing in the presence of 2,4-DAPG (Fig. 8D). Based on these results, 2,4-DAPG does not appear to affect the $\beta(1,4)$ - and $\beta(1,6)$-glucan content of the cell wall of Pythium ultimum var. sporangiiferum.

Observations of sections immunolabeled to locate $\beta(1,3)$-glucans revealed that no immunolabeling was present in control sections without primary antibody (Fig. 9A). $\beta(1,3)$-Glucans were present in both the membrane and the cytoplasm of Pythium ultimum var. sporangiiferum growing in the absence (Fig. 9B) or in the presence of 2,4-DAPG (Fig. 9C).

\section{DISCUSSION}

The results of this study show that, within and among Pythium spp., there is variation in sensitivity to 2,4-DAPG, a broadspectrum antibiotic produced by Pseudomonas biocontrol strains. Also, various propagules of Pythium ultimum var. sporangiiferum, that are part of the asexual stage of the life cycle, can differ considerably in their sensitivity to 2,4-DAPG. Mycelium was the most resistant structure, followed by zoosporangia, zoospore cysts, and zoospores. Additionally, we report for the first time that $\mathrm{pH}$ has a significant effect on the activity of 2,4-DAPG, with a higher activity at low $\mathrm{pH}$. Furthermore, the level of acetylation of PG is a major determinant of their activity. Finally, TEM studies revealed that 2,4-DAPG causes different stages of disorganization in hyphal tips of Pythium ultimum var. sporangiiferum, including alteration (proliferation, retraction, and disruption) of the plasma membrane, vacuolization, and cell content degeneration. Collectively, these results give a better understanding of the mode of action and activity of 2,4-DAPG, which may contribute to further improve the efficacy of biological control of plant pathogenic Pythium spp. by 2,4-DAPG-producing Pseudomonas spp.

Pythium spp. have a complex life cycle with multiple infectious propagules. Depending on the environmental conditions, zoospo-

\section{口0 目 16 四 24 总 $32 \square 40 \mathrm{ug} / \mathrm{ml}$ 2,4-DAPG}

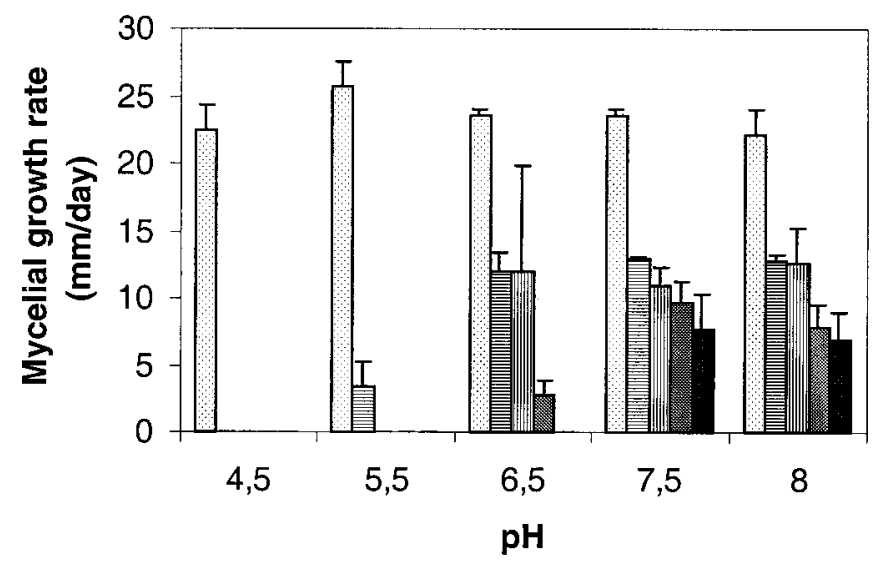

Fig. 6. Effect of pH on activity of 2,4-diacetylphloroglucinol (2,4-DAPG) against Pythium ultimum var. sporangiiferum. Growth rate of Pythium ultimum var. sporangiiferum on potato dextrose agar with buffered $\mathrm{pH}$ amended with different concentrations of 2,4-DAPG was determined by measuring the radial mycelial growth every $24 \mathrm{~h}$ during 7 days of incubation at $25^{\circ} \mathrm{C}$. Means of 10 replicates are shown. Bars of different shading correspond to different concentrations of 2,4-DAPG $\left(\mu \mathrm{g} \mathrm{ml}^{-1}\right)$. Error bars represent the standard error of the mean. The experiment was performed three times and representative results are shown. rangia may be very important propagules in the interaction between Pythium spp. and their hosts (37). The formation and diameter of Pythium ultimum var. sporangiiferum zoosporangia were significantly reduced at a 2,4-DAPG concentration of $2.0 \mu \mathrm{g} \mathrm{ml}^{-1}$. The diameter of zoosporangia is an indicator of their developmental stage because they need to reach a certain diameter to ripen and liberate zoospores (57). Several Pythium spp. reproduce asexually, forming mobile biflagellate zoospores, which are responsible for the dispersal under moist conditions. In hydroponic systems or humid soils, zoospores locate new hosts by responding to chemoattractants produced by the plant (63). Zoospores swim, accumulate on root surfaces, and encyst in response to root polysaccharides that interact with receptors on the zoospore surface (14). We found that zoospores of Pythium ultimum var. sporangiiferum stopped swimming at a 2,4-DAPG concentration of $0.8 \mathrm{ng} \mathrm{ml}^{-1}$ and almost all disintegrated at $3.2 \mathrm{ng} \mathrm{ml}^{-1}$. The high sensitivity of zoospores to 2,4-DAPG may be explained by the lack of a protective cell wall. This is supported by the observation that encysted zoospores of Pythium ultimum var. sporangiiferum, which have a cell wall, were significantly more resistant to 2,4-DAPG than nonencysted zoospores. Encysted zoospores germinate in response to host-produced amino acids and polysaccharides, causing root, stem, or seed infections (14, $19,63)$. The results of this study clearly illustrate the stimulatory effect of root exudates on cyst germination. The observed significant increase in zoospore cyst germination in water at a 2,4DAPG concentration of $3.2 \mu \mathrm{g} \mathrm{ml}^{-1}$ could be explained by stimu-

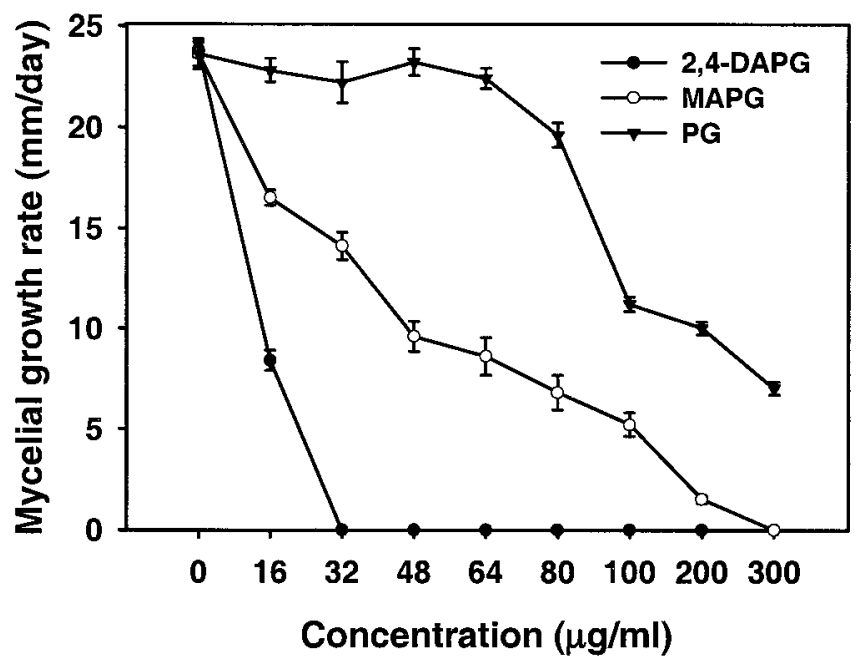

Fig. 7. Activity of different phloroglucinol derivatives against mycelial growth of Pythium ultimum var. sporangiiferum. 2,4-Diacetylphloroglucinol (2,4-DAPG), monoacetylphloroglucinol (MAPG), and phloroglucinol (PG) were added to potato dextrose agar plates $(\mathrm{pH}$ 6.5) at different concentrations. Pythium ultimum var. sporangiiferum mycelial growth was measured every $24 \mathrm{~h}$ during 7 days of incubation at $25^{\circ} \mathrm{C}$. Mean values of five replicates are shown. Error bars represent the standard error of the mean. The experiment was performed three times and representative results are shown.

TABLE 2. Effect of 2,4-diacetylphloroglucinol (2,4-DAPG) on cell structure of hyphal tips of Pythium ultimum var. sporangiiferum ${ }^{\mathrm{z}}$

\begin{tabular}{lcc}
\hline Cell structure & Control $(n=50)$ & 2,4-DAPG $(n=29)$ \\
\hline Dense cytoplasm with few vacuoles & 16 & 3 \\
Many vacuoles in the cell lumen & 56 & 7 \\
Beginning of cell disorganization & 24 & 66 \\
Deteriorated or empty cell content & 4 & 24 \\
\hline
\end{tabular}

${ }^{\mathrm{z}}$ Cell structures were observed with transmission electron microscopy and divided into four categories. Values represent the percentage of cell structures belonging to each of the four categories; $n$ represents the number of hyphal tips evaluated. 

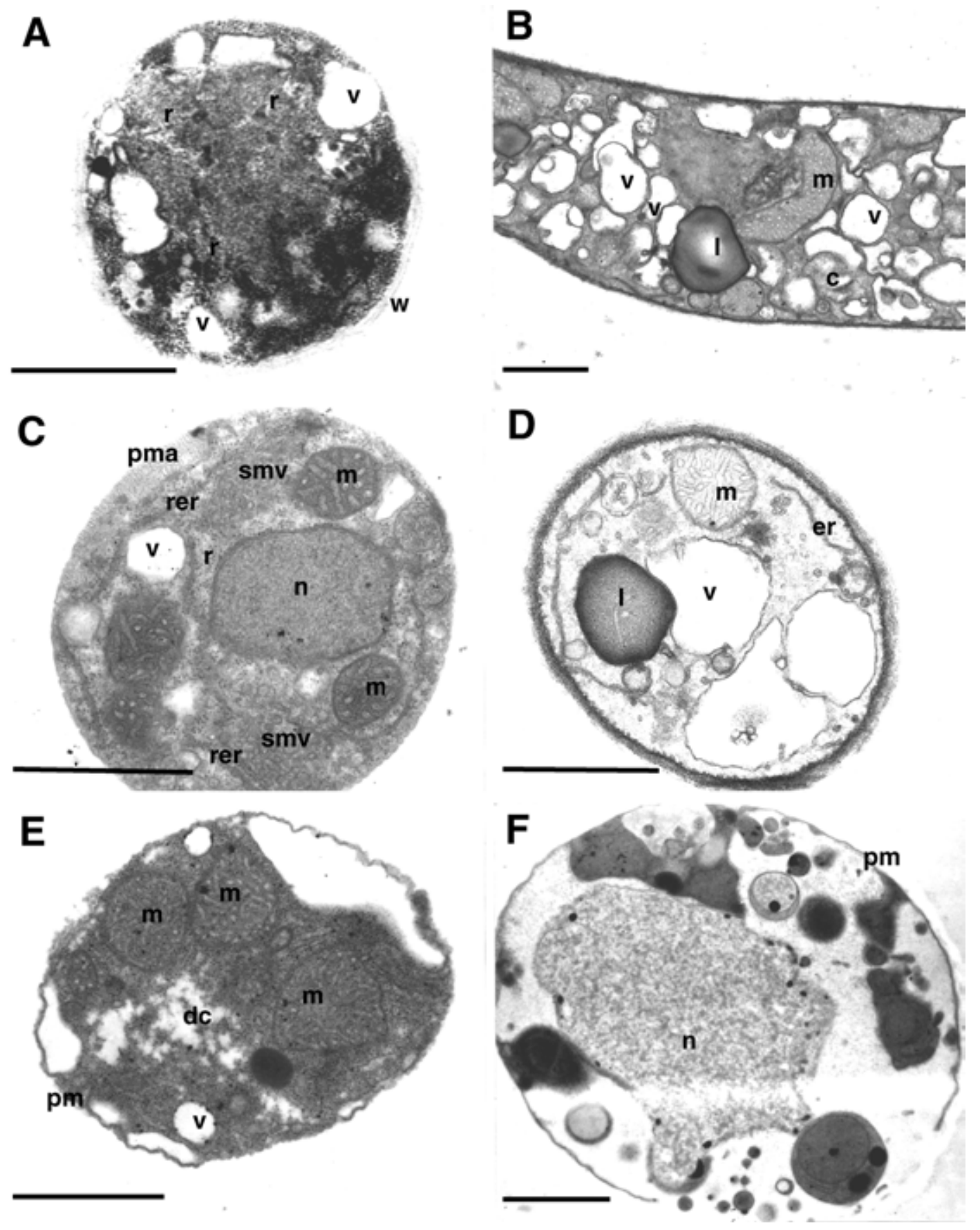

Fig. 8. Electron micrographs of hyphae of Pythium ultimum var. sporangiiferum growing on King's B medium $\mathbf{A}$ and $\mathbf{B}$, in absence or $\mathbf{C}$ to $\mathbf{F}$, in presence of 2,4-diacetylphloroglucinol. Sections were stained either by $\mathbf{A}, \mathbf{C}, \mathbf{E}$, and $\mathbf{F}$, double contrast or $\mathbf{B}$ and $\mathbf{D}$, with the periodic acid thiocarbohydrazide silver proteinate reaction; $\mathrm{c}=$ cytoplasm, $\mathrm{dc}=$ degenerated cytoplasm, $\mathrm{er}=$ endoplasmic reticulum, $\mathrm{rer}=$ rough endoplasmic reticulum, $1=$ lipid granule, $\mathrm{m}=$ mitochondria, $\mathrm{n}=$ nucleus, $\mathrm{pm}=$ plasma membrane, $\mathrm{pma}=$ plasma membrane alteration, $\mathrm{r}=$ ribosomes, $\mathrm{smv}=$ smooth membranous vesicles, $\mathrm{v}=\mathrm{vacuole}$, and $\mathrm{w}=$ electron translucent wall. $\mathrm{Bar}=1 \mu \mathrm{m}$.

lation at sublethal concentrations commonly observed with fungicides (28). For example, pyrazophos increased the sporulation of Erysiphe spp. on Rhododendron spp. at relatively low fungicide concentrations (28). Similar results were reported for benomyl, carbendazim, and sulfur, enhancing both the growth and sporulation of Drechslera teres (54). The causes of this phenomenon are not known. However, it may be interpreted as a last survival effort by the pathogen. Collectively, the results of our study suggest that 2,4-DAPG-producing Pseudomonas spp. may be much more effective in biological control of Pythium spp. that infect host plants primarily by means of zoospores, or under specific environmental conditions where zoospores play a much more prominent role in the disease cycle.
Among the different Pythium spp. tested in this study, variation in sensitivity of mycelial growth to 2,4-DAPG was observed. Mazzola et al. (36) showed that various isolates of the take-all fungus Gaeumannomyces graminis var. tritici can differ substantially in their sensitivity toward 2,4-DAPG; isolates that were relatively insensitive to 2,4-DAPG in vitro could no longer be suppressed in situ by a 2,4-DAPG-producing Pseudomonas strain. Their work clearly illustrated that variation in sensitivity within target pathogen populations to specific metabolites produced by antagonistic microorganisms can be an important factor in the inconsistency of biological control encountered under field conditions. The variation in sensitivity among and within Pythium spp. to 2,4-DAPG, combined with the fact that many pathogenic 

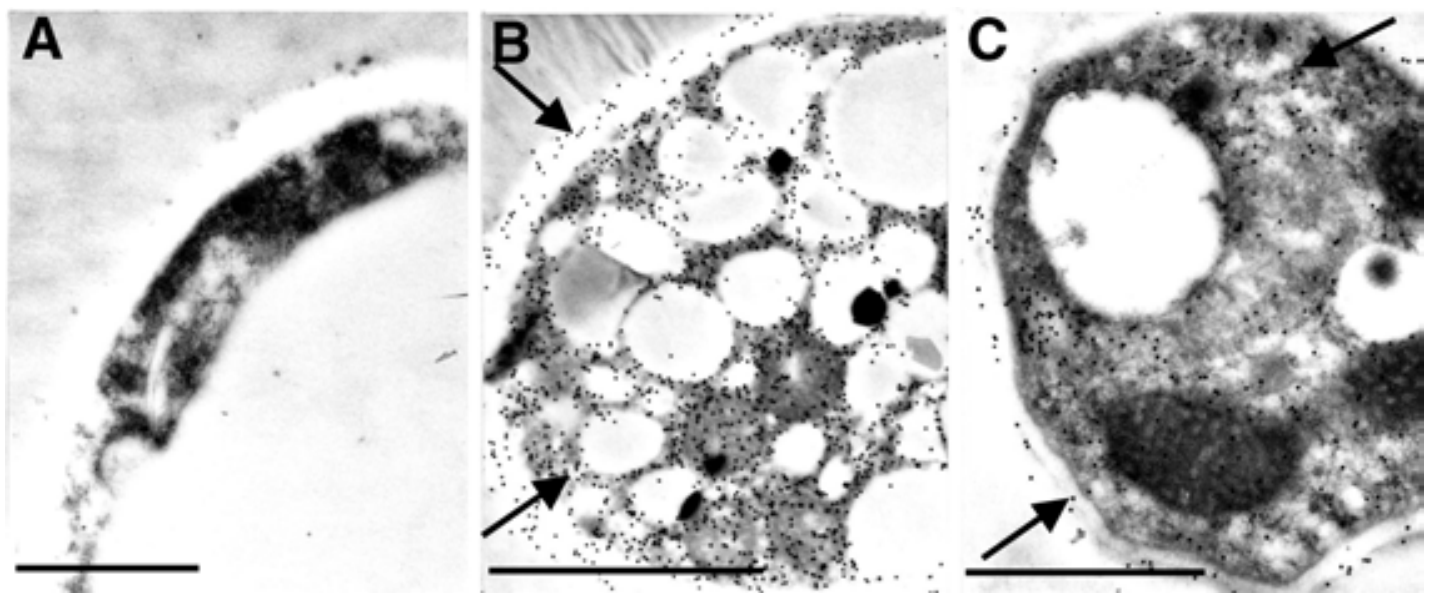

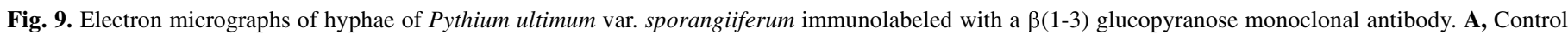

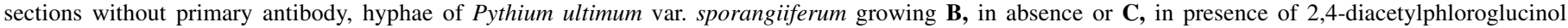
$(400 \mu \mathrm{g} / \mathrm{disk})$. Arrows indicate immunolabeling. Bar $=1 \mu \mathrm{m}$.

species can occur simultaneously at the same site (9), may have a significant impact on the success, or at least the consistency, of biological control provided by 2,4-DAPG-producing strains. It should be emphasized, however, that our study included only a limited number of species and one or two isolates of a given species. Whether the level of variation in sensitivity reported in this study is representative for all individual isolates that belong to a given species remains to be determined.

The role of environmental conditions in 2,4-DAPG production has been studied both in vitro and in situ for a number of Pseudomonas strains $(18,38,45)$. These studies demonstrated that the regulation of production of this antibiotic through physiological factors may vary among strains. For example, 2,4-DAPG production was stimulated by glucose in Pseudomonas fluorescens strain CHA0 and repressed in strain F113. In this study, we showed that $\mathrm{pH}$ has a significant effect on the activity of 2,4DAPG against mycelial growth of Pythium ultimum var. sporangiiferum: the lower the $\mathrm{pH}$, the higher the activity of 2,4DAPG. This suggests that the temporal and spatial changes that may occur in the nutritional and physical conditions of microsites where 2,4-DAPG-producing strains are operating will influence not only the production but also the activity of 2,4-DAPG. Changes in $\mathrm{pH}$ in the rhizosphere of plants, growing in agricultural soils, by as much as $2 \mathrm{pH}$ units may occur (39). In general, the $\mathrm{pH}$ changes induced by roots lead to acidification, with more pronounced effects observed for dicot plants (35). Also microorganisms, including pathogenic fungi, can alter the $\mathrm{pH}$ to make nutrients or trace elements more readily available (13). As a result of these changes in $\mathrm{pH}$, the activity of antimicrobial compounds produced by competing microorganisms may change. In this study, we observed that Pythium ultimum var. sporangiiferum acidifies unbuffered, liquid medium (potato dextrose broth) in a 7-day period from $\mathrm{pH} 6.5$ to 4.5 (data not shown). This reduction in $\mathrm{pH}$ and coordinate increase in toxicity of 2,4-DAPG may explain some of the discrepancies in inhibitory concentrations of 2,4-DAPG reported in the different experiments presented in this study. To our knowledge, this is the first time that the effect of $\mathrm{pH}$ on the toxicity of 2,4-DAPG has been reported. The lower activity of 2,4-DAPG at high $\mathrm{pH}$ possibly is related to a dissociation of the hydroxyl-substituents of 2,4-DAPG, which may hamper accumulation into the target cell. Similar results have been described for another antibiotic, phenazine-1-carboxilic acid (PCA), produced by Pseudomonas fluorescens 2-79, a strain that was more active against $G$. graminis var. tritici at lower $\mathrm{pH}$ (8). A comparison between PCA from strain 2-79 and phenazine-1-carboxamide (PCN) from Pseudomonas chlororaphis PCL 1391 showed that both phenazines have the same activity at $\mathrm{pH}$ levels lower than
5.0. However, $\mathrm{PCN}$ remained active at higher $\mathrm{pH}$, whereas the activity of PCA decreased significantly (10). Nevertheless, no determinative effect of $\mathrm{pH}$ was found when strain 2-79 was introduced in soil (40). Probably, $\mathrm{pH}$ exerts greater influence in microsites in the rhizosphere, which are considered to be the courts of interaction between biocontrol agents and root pathogens. A better understanding of the interactions in these microsites is being explored by molecular techniques, including the use of reporter genes $(4,38,43)$.

The differences in activity of the PG derivatives PG, MAPG, and 2,4-DAPG indicated that the higher the level of acetylation, the higher the activity against mycelial growth of Pythium ultimum var. sporangiiferum. Given that, in several Pseudomonas strains, the amounts produced and the ratio of MAPG to 2,4DAPG may vary depending on biotic and abiotic factors (17), one may envisage that the biocontrol activity will change accordingly.

Although many activities of 2,4-DAPG are well documented $(1,11,15,23,24,26,30,50,51,60)$, its mode of action was unclear. PG derivatives were reported as potent inhibitors of the photosystem II in plants $(55,61)$. Typical ultrastructural changes observed in fungi exposed to other phenolic fungicides, such as quintozene, chloroneb, and phenylphenol, include lysis of the inner mitochondrial membranes, vacuolization of the nuclear envelope, and increases in cell wall thickness (34). In our studies, however, no such symptoms were observed in Pythium ultimum var. sporangiiferum hyphal tips exposed to 2,4-DAPG. Instead, based on TEM observations, it appears that 2,4-DAPG does not affect the cell wall structure and composition of hyphal tips of Pythium ultimum var. sporangiiferum, because $\beta(1,3)-, \beta(1,4)$-, and $\beta(1,6)$-glucans were equally present in hyphal tips exposed or not to 2,4-DAPG. The extensive network of the membranous vesicles closely associated with the rough endoplasmic reticulum are likely to be transport or secretion vesicles which may accumulate as a result of stimulation of the development and activity of the Golgi apparatus by 2,4-DAPG. Alternatively, the accumulation of secretion vesicles derived from Golgi bodies may result from inhibition of hyphal elongation through a yet unknown mechanism of action of 2,4-DAPG. Localized alteration in plasma membrane organization may indicate disruption or proliferation, due to increased Golgi vesicle trafficking.

\section{ACKNOWLEDGMENTS}

This research was financially supported by CAPES, Brazil (Project 1515/96-9) and by the Royal Dutch Academy of Arts and Sciences. We thank M. A. de Waard and P. de Wit for critically reading the manuscript 
and for their valuable suggestions, and T. Corberand and D. Kraaijeveld for their practical assistance.

\section{LITERATURE CITED}

1. Arisawa, M., Fujita, A., Hayashi, T., Hayashi, K., Ochiai, H., and Morita, N. 1990. Cytotoxic and antiherpetic activity of phloroglucinol derivatives from Mallotus japonicus (Euphorbiaceae). Chem. Pharm. Bull. 38:1624-1626.

2. Bangera, M. G., and Thomashow, L. S. 1996. Characterization of a genomic locus required for synthesis of the antibiotic 2,4-diacetylphloroglucinol by the biological control agent Pseudomonas fluorescens Q287. Mol. Plant-Microbe Interact. 9:83-90.

3. Bangera, M. G., and Thomashow, L. S. 1999. Identification and characterization of a gene cluster for synthesis of the polyketide antibiotic 2,4diacetylphloroglucinol from Pseudomonas fluorescens Q2-87. J. Bacteriol. 181:3155-3163.

4. Bloemberg, G. V., Wijfjes, A. H. M., Lamers, G. E. M., Stuurman, N., and Lugtenberg, B. J. J. 2000. Simultaneous imaging of Pseudomonas fluorescens WCS365 populations expressing three different autofluorescent proteins in the rhizosphere: New perspectives for studying microbial communities. Mol. Plant-Microbe Interact. 13:1170-1176.

5. Blumer, C., and Haas, D. 2000. Iron regulation of the hcnABC genes encoding hydrogen cyanide synthase depends on the anaerobic regulator ANR rather than on the global activator GacA in Pseudomonas fluorescens CHA0. Microbiology 146:2417-2424.

6. Bokesch, H. R., Groweiss, A., McKee, C. T., and Boyd, M. R. 1999. Laxifloranone, a new phloroglucinol derivative from Marila laxiflora. J. Nat. Prod. 62:1197-1199.

7. Bonsall, R. F., Weller, D. M., and Thomashow, L. S. 1997. Quantification of 2,4-diacetylphloroglucinol produced by fluorescent Pseudomonas sp. in vitro and in the rhizosphere of wheat. Appl. Environ. Microbiol. 63:951-955.

8. Brisbane, P. G., Janik, L. J., Tate, M. E., and Warren, R. F. O. 1987. Revised structure for the phenazine antibiotic from Pseudomonas fluorescens 2-79 (NRRL B-15132). Antimicrob. Agents Chemother. 31: 1967-1971.

9. Chamswarng, C., and Cook, R. J. 1985. Identification and comparative pathogenicity of Pythium species from roots and wheat-field soils in the Pacific Northwest. Phytopathology 75:821-827.

10. Chin-A-Woeng, T. F. C., Bloemberg, G., van der Bij, A., van der Drift, K. M. G. M., Schripsema, J., Kroon, B., Scheffer, R. J., Keel, C., Bakker, P. A. H. M., Tichy, H.-V., de Bruijn, F. J., Thomas-Oates, J. E., and Lugtenberg, B. J. J. 1998. Biocontrol by phenazine-1-carboxamideproducing Pseudomonas chlororaphis PCL1391 of tomato root and crown rot caused by Fusarium oxysporum f. sp. radicis-lycopersici. Mol. Plant-Microbe Interact. 11:1069-1077.

11. Cronin, D., Moenne-Loccoz, Y., Fenton, A., Dunne, C., Dowling, D. N., and O'Gara, F. 1997. Role of 2,4-diacetylphloroglucinol in the interactions of the biocontrol pseudomonad strain F113 with the potato cyst nematode Globodera rostochiensis. Appl. Environ. Microbiol. 63:1357-1361.

12. Cronin, D., Moenne-Loccoz, Y., Fenton, A., Dunne, C., Dowling, D. N., and O'Gara, F. 1997. Ecological interaction of a biocontrol Pseudomonas fluorescens strain producing 2,4-diacetylphloroglucinol with the soft rot potato pathogen Erwinia caratovora subsp. atroseptica. FEMS Microbiol. Ecol. 23:95-106.

13. Cunningham, J. E., and Kuiack, C. 1992. Production of citric and oxalic acids and solubilization of calcium-phosphate by Penicillium bilaii. Appl. Environ. Microbiol. 58:1451-1458.

14. Deacon, J. W., and Donaldson, S. P. 1993. Molecular recognition in the homing responses of zoosporic fungi, with special reference to Pythium and Phytophthora. Mycol. Res. 97:1153-1171.

15. Debabrata, S., and Naik, P. 2000. Phloroglucinol enhances growth and rate of axillary shoot proliferation in potato shoot tip cultures in vitro. Plant Cell Tissue Organ Cult. 60:139-149.

16. Dick, M. W. 1990. Keys to Pythium. Reading University Press, Reading, England.

17. Duffy, B. K., and Défago, G. 1997. Zinc improves biocontrol of fusarium crown and root rot of tomato by Pseudomonas fluorescens and represses the production of pathogen metabolites inhibitory to bacterial antibiotic biosynthesis. Phytopathology 87:1250-2157.

18. Duffy, B. K., and Défago, G. 1999. Environmental factors modulating antibiotic and siderophore biosynthesis by Pseudomonas fluorescens biocontrol strains. Appl. Environ. Microbiol. 65:2429-2438.

19. Estrada-Garcia, T., Ray, T. C., Green, J. R., Callow, J. A., and Kennedy, J. F. 1990. Encystment of Pythium aphanidermatum zoospores is induced by root mucilage polysaccharides, pectin and a monoclonal antibody to a surface antigen. J. Exp. Bot. 41:693-699.
20. Fenton, A. M., Stephens, P. M., Crowley, J., O'Callaghan, M., and O'Gara, R. 1992. Exploitation of gene(s) involved in 2,4-diacetylphloroglucinol biosynthesis to confer a new biocontrol capability to a Pseudomonas strain. Appl. Environ. Microbiol. 58:3873-3878.

21. Gianinazzi, S., and Gianinazzi-Pearson, V. 1992. Cytology, histochemistry and immunocytochemistry as tools for studying structure and function in endomycorrhiza. Methods Microbiol. 24:109-139.

22. Ishiguro, K., Nagareya, N., and Fukumoto, H. 1998. A phloroglucinol derivative from cell suspension cultures of Hypericum palatum. Phytochemistry 47:1041-1043.

23. Ito, H., Muranaka, T., Mori, K., Jin-ZheXiong, Tokuda, H., Nishino, H., Yoshida, T., and Jin, Z. X. 2000. Ichthyotoxic phloroglucinol derivatives from Dryopteris fragrans and their anti-tumor promoting activity. Chem. Pharm. Bull. 1190-1195.

24. James, D. J. 1979. The role of auxins and phloroglucinol in adventitious root formation in Rubus and Fragaria in vitro. J. Hortic. Sci. 54:273277.

25. Jimenez-Escrig, A., Jimenez-Jimenez, I., Pulido, R., and Saura-Calixto, F. 2001. Antioxidant activity of fresh and processed edible seaweed. J. Sci. Food Agric. 81:530-534.

26. Keel, C., Schnider, U., Maurhofer, M., Voisard, C., Laville, J., Burger, U., Wirthner, P. H., Haas, D., and Défago, G. 1992. Suppression of root diseases by Pseudomonas fluorescens CHA0: Importance of the secondary metabolite 2,4-diacetylphloroglucinol. Mol. Plant-Microbe Interact. 5:4-13.

27. Keel, C., Wirthner, P. H., Oberhansli, T. H., Voisard, C., Burger, U., Haas, D., and Défago, G. 1990. Pseudomonads as antagonists of plant pathogens in the rhizosphere: Role of the antibiotic 2,4-diacetylphloroglucinol in the suppression of black root rot of tobacco. Symbiosis 9:327-342

28. Kenyon, D. M., Dixon, G. R., and Helfer, S. 1997. The repression and stimulation of growth of Erysiphe sp. on Rhododendron by fungicidal compounds. Plant Pathol. 46:425-431.

29. King, E. O., Ward, M. K., and Raney, D. E. 1954. Two simple media for the demonstration of pyocyanin and fluorescin. J. Lab. Clin. Med. 44:301-307.

30. Lawler, I. R., Eschler, B. M., Schliebs, D. M., and Foley, W. J. 1999. Relationship between chemical functional groups on Eucalyptus secondary metabolites and effectiveness as marsupial antifeedants. J. Chem. Ecol. 25:2561-2573.

31. Lemoine, M. C., Gollotte, A., and Gianinazzi-Pearson, V. 1995. Localization of beta(1-3) glucan in walls of the endomycorrhizal fungi Glomus mosseae (Nicol. \& Gerd.) Gerd. \& Trappe and Acaulospora laevis Gerd. \& Trappe during colonization of host roots. New Phytol. 129:97-105.

32. Levy, E., Gough, F. J., Berlin, K. D., Guiana, P. W., and Smith, J. T. 1992. Inhibition of Septoria tritici and other phytopathogenic fungi and bacteria by Pseudomonas fluorescens and its antibiotics. Plant Pathol. 41:335-341.

33. Loper, J. E., and Lindow, S. E. 1997. Reporter gene systems useful in evaluating in situ gene expression by soil and plant-associated bacteria. Pages 482-492 in: Manual of Environmental Microbiology. C. J. Hurst, G. R. Knudsen, M. J. McInerney, L. D. Stetzenbach, and M. V. Walter, eds. American Society for Microbiology, Washington.

34. Lyr, H. 1995. Aromatic hydrocarbon fungicides and their mechanism of action. Pages 76-98 in: Modern Selective Fungicides: Properties, Applications, Mechanisms of Action, 2nd ed. H. Lyr, ed. Gustav Fischer Verlag, Jena, Germany.

35. Marschner, H., and Römheld, V. 1983. In vivo measurement of rootinduced $\mathrm{pH}$ changes at the soil-root interface: Effect of plant species and nitrogen source. Z. Pflanzenphysiol. 111:241-251.

36. Mazzola, M. F., Fujimoto, D. K., Thomashow, L. S., and Cook, R. J. 1995. Variation in sensitivity of Gaeumannomyces graminis to antibiotics produced by Pseudomonas spp. and effect on biological control of take-all of wheat. Appl. Environ. Microbiol. 61:2554-2559.

37. Nelson, E. B., and Hsu, J. S. T. 1994. Nutritional factors affecting responses of sporangia of Pythium ultimum to germination stimulants. Phytopathology 84:677-683.

38. Notz, R., Maurhofer, M., Schnider-Keel, U., Duffy, B., Haas, D., and Défago, G. 2001. Biotic factors affecting expression of the 2,4-diacetylphloroglucinol biosynthesis gene phlA in Pseudomonas fluorescens strains CHA0 in the rhizosphere. Phytopathology 91:873-881.

39. Nye, P. H. 1981. Changes in the $\mathrm{pH}$ across the rhizosphere induced by roots. Plant Soil 61:7-26.

40. Ownley, B. H., Weller, D. M., and Thomashow, L. S. 1992. Influence of in situ and in vitro $\mathrm{pH}$ on suppression of Gaeumannomyces graminis var. tritici by Pseudomonas fluorescens 2-79. Phytopathology 82:178-184.

41. Raaijmakers, J. M., Bonsall R. F., and Weller, D. M. 1999. Effect of population density of Pseudomonas fluorescens on production of 2,4diacetylphloroglucinol in the rhizosphere of wheat. Phytopathology 89:470-475. 
42. Reynolds, E. S. 1983. The use of lead citrate at high $\mathrm{pH}$ as an electron opaque stain in electronic microscopy. J. Cell Biol. 17:208-212.

43. Sankarasubramanian, S., and Kaushik, B. D. 2001. Development of genetic markers in cyanobacteria and stability of genetically marked strains in soil. World J. Microbiol. Biotechnol. 17:535-544.

44. Sarniguet, A., Kraus, J., Henkels, M. D., Muehlchen, A. M., and Loper, J. E. 1995. The sigma factor $\sigma^{\mathrm{S}}$ affects antibiotic production and biological control activity of Pseudomonas fluorescens Pf-5. Proc. Natl. Acad. Sci. USA 92:12255-12259.

45. Shanahan, P., O'Sullivan, D. J., Simpson, P., Glennon, J. D., and O'Gara, F. 1992. Isolation of 2,4-diacethylphloroglucinol from a fluorescent pseudomonad and investigation of physiological parameters influencing its production. Appl. Environ. Microbiol. 58:353-358.

46. Shanahan, P., O’Sullivan, D. J., Simpson, P., Glennon, J. D., and O'Gara, F. 1993. Liquid chromatographic assay of microbially derived phloroglucinol antibiotics for establishing the biosynthetic route to production, and the factors affecting their regulation. Anal. Chim. Acta 272:271-277.

47. Sharifi-Tehrani, A., Zala, M., Natsch, A., Moënne-Loccoz, Y., and Défago, G. 1998. Biocontrol of soil-borne fungal diseases by 2,4diacetylphloroglucinol-producing pseudomonads with different restriction profiles of amplified 16S rDNA. Eur. J. Plant Pathol. 104:631-643.

48. Strunz, G. M., Wall, R. E., and Holder-Franklin, M. A. 1978. Phloroglucinol derivatives from Aeromonas hydrophila. J. Antibiot. (Tokyo) 31:1201-1202.

49. Stutz, E., Défago, G., and Kern, H. 1986. Naturally occurring fluorescent pseudomonad involved in suppression of black root rot of tobacco. Phytopathology 76:181-185.

50. Tada, M., Takakuwa, T., Nagai, M., and Yoshii, T. 1990. Antiviral and antimicrobial activity of 2,4-diacetylphloroglucinols, 2-acylcyclohexane1,3-diones and 2-carboxamidocyclohexane-1,3-diones. Agric. Biol. Chem. 54:3061-3063.

51. Te-Chato, S., and Lim, M. 1999. Plant regeneration of mangosteen via nodular callus formation. Plant Cell Tissue Organ Cult. 59:89-93.

52. Thièry, J. P. 1967. Mise en évidence des polysaccharides sur des coupes fines en microscopie électronique. J. Microsc. (Oxf.) 6:987-1018.

53. Thomashow, L. S., Bonsall, R. F., and Weller, D. M. 1997. Antibiotic production by soil and rhizosphere microbes in situ. Pages 493-499 in: Manual of Environmental Microbiology. C. J. Hurst, G. R. Knudsen, M. J. McInerney, L. D. Stetzenbach, and M. V. Walter, eds. American Society for Microbiology, Washington.

54. Toubia-Rahme, H., Ali-Haimoud, D. E., Barrault, G., and Albertini, L. 1995. Effect of four fungicides on barley net blotch caused by Drecheslera teres. J. Phytopathol. 143:335-339.

55. Trebst, A., Donner, W., and Draber, W. 1984. Structure activity correlation of herbicides affecting plastoquinone reduction by photosystem II: Electron density distribution in inhibitors and plastoquinone species. Z. Naturforsch. C. Biosci. 39:405-411.

56. Valentine, R. C. 1961. Contrast enhancement in the electron microscopy of viruses. Adv. Virus Res. 8:287-290.

57. Van der Plaats-Niterink, A. J. 1981. Monograph of the genus Pythium. Page 244 in: Studies in Mycology, 21. Centraalbureau voor Schimmelcultures, Baarn, The Netherlands.

58. Verrota, L., Appendino, G., Belloro, E., Jakupovic, J., and Bombardelli, E. 1999. Furohyperforin, a prenylated phloroglucinol from St. John's Wort (Hypericum perforatum). J. Nat. Prod. 62:770-772.

59. Vincent, M. N., Harrison, L. A., Brackin, J. M., Kovacevich, P. A., Mukerji, P., Weller, D. M., and Pierson, E. A. 1991. Genetic analysis of the antifungal activity of a soilborne Pseudomonas aureofacens strain. Appl. Environ. Microbiol. 57:2928-2934.

60. Yajima, T., and Munakata, K. 1979. Phloroglucinol-type furocumarins, a group of potent naturally-occurring insect antifeedants. Agric. Biol. Chem. 43:1701-1706.

61. Yoneyama, K., Konnai, M., Honda, I., Yoshida, S., Takahashi, N., Koike, H., and Inoue, Y. 1990. Phloroglucinol derivatives as potent photosystem inhibitors. Z. Naturforsch. C. Biosci. 45:317-321.

62. Whistler, C. A., Corbell, N. A., Sarniguet, A., Ream, W., and Loper, J. E. 1998. The two-component regulators gacS and gacA influence accumulation of the stationary-phase sigma factor $\sigma^{\mathrm{S}}$ and the stress response in Pseudomonas fluorescens Pf-5. J. Bacteriol. 180:6635-6641.

63. Zhou, T., and Paulitz, T. C. 1993. In vitro and in vivo effects of Pseudomonas spp. on Pythium aphanidermatum: Zoospore behavior in exudates and on the rhizoplane of bacteria-treated cucumber roots. Phytopathology 83:872-876. 